\section{From Subprime and Eurozone Crisis with Full Speed into the Next Financial Crisis}

\author{
Sebastjan Strašek \\ University of Maribor, Faculty of Economics and Business, Slovenia \\ sebastjan.strasek@um.si
}

\begin{abstract}
This paper offers an analysis of the road from subprime and eurozone crisis to the elements of a new systemic crisis. Our aim is to research common issues that accompany each of these crises and to explore elements that hint that the financial systems are moving toward a new crisis. By holding short-term interest rates near zero, the central banks have encouraged malinvestment and speculation. Fuelling the bubble is the fear of missing out on trade. We find that actual events and movements on security markets follow a typical pattern, which indicates a serious threat for the next financial crisis. We also find enough signs that old crises lessons haven't been learned.
\end{abstract}

Keywords: financial crisis, bubble, $\mathrm{P} / \mathrm{E}$ ratio

\section{Introduction}

The subprime, global, and eurozone crisis has reignited a new interest in understanding equity bonds, credit, and interest rate fluctuations in the macroeconomy and the crucial role they could play in generation of shocks. These financial crises have prompted empirical and theoretical research aiming at capturing the interactions between the financial and the real side of the economy. We find there is a renewed interest in correlations between macro-variables across broad ranges of countries and time periods, as in Reinhart and Rogoff (2009), Claessens et al. (2011), Schularick and Taylor (2012).

Historically, the study of the business cycle has focused on the behaviour of macroeconomic data with cycles lasting on average no more than eight years. But the recent evidence tells us that real and financial variables interact at lower frequencies than those of the traditional business cycles (Aikman et al., 2014, Drehmann et al., 2012). Research findings (Communale, Hessel, 2014) suggest that the domestic demand booms related to financial cycles may have been more important. Drehmann et al. (2012) and Borio (2012) reveal several characteristics of the financial cycle. First, the financial cycle is mainly driven by credit and house price growth. Second, the financial cycle has a much wider amplitude and longer duration than normal business cycles. While normal business cycles have a frequency of up to eight years, the frequency of the financial cycle is thought to be between 16 and 20 years. Finally, a downturn of the financial cycle is often accompanied by a financial crisis.
ORIGINAL SCIENTIFIC PAPER

RECEIVED: JULY 2017

REVISED: AUGUST 2017

ACCEPTED: AUGUST 2017

DOI: 10.1515/ngoe-2017-0013

UDK: 338.124 .4

JEL: W32, G01, G12

Citation: Strašek, S. (2017). From

Subprime and Eurozone Crisis with Full

Speed into the Next Financial Crisis. Naše Gospodarstvo/Our Economy, 63(3), 3-11. DOI: 10.1515/ngoe-2017-0013

\section{NG OE}

NAŠE GOSPODARSTVO OUR ECONOMY

\section{vol.63 No.3 2017}

pp. 3-11 
This paper offers an analysis of the road from subprime and eurozone crisis to the elements of a new systemic crisis. Our aim is to research common issues that accompany each of these crises and to explore elements that hint that financial systems are moving toward new crisis. The paper is organized as follows. After the introduction in Section 2, we investigate what transforms a significant, but relatively mild financial disruption - subprime residential mortgages - into a full-fledged global financial crisis. Section 3 examines some important stylized facts of the drivers in the run-up to eurozone crisis. In Section 4, we discuss some growing signs of the next financial crisis. Section 5 concludes.

\section{Subprime Crisis: Issues}

Baily et al. (2008) find that the subprime crisis had it origins in an asset price bubble that interacted with new kinds of financial innovations that masked risks; with companies that failed to follow their own risk management procedures; and with regulators and supervisors who failed to restrain excessive risk taking. The exponential growth of subprime lending after 2000 is due to the sustained rise in house prices along with financial innovations in the form of adjustable rate mortgages. Another important element of innovations was the so-called process of securitizing mortgages: collateralized debt obligations, structure investment vehicles, overnight repurchase agreements (repo loans), and asset-backed commercial papers became an important source of funding for many large institutions and a way for banks to rely on shorter-term borrowing to find their assets. When this kind of funding suddenly dried up, financial institutions effectively faced a "run" and found themselves exposed with very little capital. Grenlaw et al. (2008) find that while commercial banks were on average leveraged 9.8:1, broker/ dealers and hedge funds were leveraged at nearby 32:1, GSE (financial services corporation created by US Congress, like Fannie Mae and Freddie Mac) were leveraged at 24:1, even though they were regulated.

Another important element in this chain represents the growth of credit insurers and credit default swaps. The transactions with these instruments were done in over the counter (OTC) markets, so these were not overseen by any regulatory body, and there was no information and no public knowledge as to have many CDS transactions most institutions have made. Experts (Mishkin, 2010; Baily et al., 2008) admit that, while securitization was meant to spread out risk away from the center of financial system, exactly the opposite happened. When the subprime credit crisis hit in August 2007, risk that meant to be dispersed throughout the system was, in fact, heavily concentrated among leveraged institutions at the heart of the system. Mishkin
(2010) points out that signals of the resulting credit market disruptions appear in the interest rate spreads between safe and risky financial instruments. Data show that the TED spread jumped from an average of around 40 basis points before August 7, 2007, to 240 points by August 20, 2007. TED spread is calculated as the gap between three-month LIBOR (an average of interest rates offered in the London interbank market for three-month dollar-denominated loans) and the three-month treasury bill rate. The size of this gap presumably reflects some sort of risk or liquidity premium. We saw the continuation of this scenario in 2008 by the rise in the spread between interest rates on Baa corporate bonds and treasury bonds. The following chain of events therefore didn't surprise: the collapse of a major housing boom in the US, the plunge of mortgage backed securities, a crisis in the US Shadow banking system, liquidity shortages in the interbank wholesale markets, the spread to European banks via the drying up inter bank liquidity, and global downturn.

The meltdown spilled over from the US into other markets: Europe was the first area affected; thereafter, its contagion spread to the rest of the world. We agree with findings of researchers (Shirai, 2009) that the subprime crisis in the US is far more complicated in that any series of crises in the past and therefore is worth analyzing its lessons: (1) absence of precise information on OTC markets; (2) avoiding of regulatory requirements. Capital adequacy requirements were applicable only to deposit-taking banks, not to other financial institutions, which resulted in expansion to securitization and derivatives; (3) commercial banks attempted to circumvent regulatory monitoring by establishing SIVs and moving to other off-balance sheet activities; (4) unableness of credit rating agencies to spot excesses; (5) financial markets are always subject to self-fulfilling prophesis; (6) accelerated contagion across countries and markets.

\section{Eurozone Crisis: Origins}

Two main views have emerged about eurozone crisis. The first, so-called German view (Allesandrini et al., 2012), prescribes the necessity of fiscal austerity in the south of the eurozone to lessen the risk that the south may be forced to abandon the euro; the second, called the Keynesian view (Merler \& Pisani-Ferry, 2012), which treat the eurozone sovereign debt crisis as being a balance-of-payment crisis, with the eurozone north benefiting from surpluses and the eurozone south suffering from deficits. This interpretation argues that the emphasis on fiscal austerity being counterproductive, given its negative impact on expected long-term growth rates (DeLong \& Summers, 2012). Stylized facts and empirical evidence (Alessandrini et al., 2012; Sanches \& Varoudakis, 2013) suggest, however, that both the fiscal 
fragility of the south and the north-south divide of external imbalances have contributed to the eurozone crisis.

Debt financed consumption was among the chief causes as well as the global financial crisis and eurozone crisis (Strasek 2015). European stability and growth pact laid out in the 1990s with a goal to limit countries' budget deficits and total debt loans produced fast convergence of interest rates among Eurozone countries. Chinn and Frieden (2012) warned that investors interpreted the creation of the union as an implicit guarantee of members countries' government debt. These implicit guarantees pushed interest rates lower, which gave governments, businesses, and households incentive to borrow more than they would have had they properly understood the risks. This situation leads to a debt overhang and financial distress. Details of the debt overhang vary from country to country: in Greece and Portugal, massive capital flows were used to finance consumption; in Spain and Ireland, capital was used to sustain massive construction booms. Divergences in domestic demand growth in the euro area have been sizeable (Figure 1). The financial cycle led to booms and busts in domestic demand in Spain, Ireland, and Greece. By contrast, it allowed Portugal and Italy to mask low potential growth and to finance growing trade deficits that might be unsustainable under less benign financial conditions. Many of the core countries did not suffer from financial imbalances and therefore had a much less extreme reversal in domestic demand. This hold especially for Germany and Austria (Communale, Hessel, 2014).

The result of north-south imbalances within Eurozone was seen in corresponding changes in net international asset position. Greece, Ireland, Italy, Portugal and Spain accumulated a large net foreign liability position, which amounts to about $20 \%$ of the Eurozone's GDP. The eurozone pattern shows diverging trends in credit growth and interest rates in the eurozone periphery and core countries growth of credit to the private sector in the periphery surpassed by far credit in the core. The credit boom was accompanied by a decline in real long-term interest rates, which were significantly steeper in the periphery than in the core. The investment rate in the periphery grew, and savings rate declined; thus, this pattern materialized as current account deficits.

There were huge differences across countries of the eurozone in credit conditions. During the years of the credit boom, average interest rates on mortgages actually paid by borrowers in periphery (Ireland, Spain) were much lower relative to core members. Also credit access was easier in the periphery, allowing in Spain and Ireland loan-to-value ratios of 100\%, compared with $60 \%$ in core countries. Jordà et al. (2011) show that the link between credit booms and current account deficits has become much closer in recent decade, so there is again a suggestion for the so-called financial cycle.

The eurozone experience seems to suggest that public debt is not sufficient as an explanation. The comparison of government debt levels and primary government balances in the eurozone south suggest that yield spreads may be a symptom rather than a proximate cause of the malady and that fiscal fundamentals are not enough to explain sovereign risk (Dadush \& Wyne, 2012). Moreover, De Grauwe and Ji (2012) find evidence that a significant part of the surge in the spreads of the PIGS countries was disconnected from underlying increases in the debt-to-GDP ratios and fiscal space variables but rather was the result of negative self-fulfilling market sentiments that become strong at the end of 2010 . The authors argue that this phenomenon can drive member countries of the eurozone into bad equilibria. There is no doubt that fiscal policy is vital to a viable monetary union. But this must be accompanied by the resolution of two main problems: the large intra-euro current account imbalances

Figure 1. Divergences in Domestic Demand Growth in the Euro Area

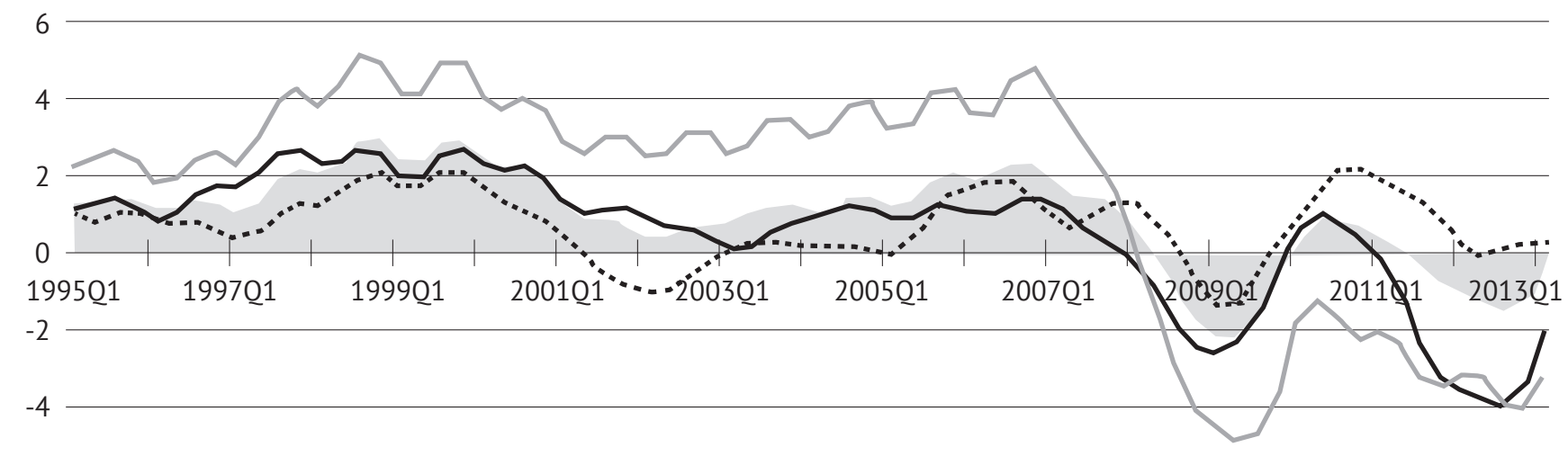

$-6$

EMU - Portugal \& Italy 
and the emergence of massive cross-border capital flight (Sinn \& Wollmershauser, 2011).

Holinski et al. (2012) provide evidence of the persistently rising current account imbalances within the euro area. Since 1991 the average current account balance of the north (Germany, Netherland, Austria, and Finland) has continuously grown from a small deficit in 1992 to a deficit of more than $6 \%$ of GDP in 2007, while at the same time the current account of South (Greece, Ireland, Portugal, Spain) has deteriorated from close to zero in the early 1990s to a deficit of almost $10 \%$ in 2007. Figure 2 shows that the strong divergence in current account imbalances is due mostly to private-sector behavior, where reduction in net private savings in the south was probably induced by lower real interest rates and increased availability of financial assets. Divergent consumer spending trends were a key driver of euro-area imbalances, as euro-area periphery households responded to lower interests by borrowing and spending. While Germany's consumption remained essentially flat after 2001, Irish real consumption spending increased roughly 55\% from 1999 to 2007, Greek and Spain roughly 35\%.

Higgins and Klitgaard (2012) confirm that pre-crisis borrowing by the periphery countries went mainly to finance private consumption or housing booms rather than productivity - enhancing investments. In this way, such investment in non-tradable sector generates no foreign income stream to support repayment. The 2007 average net foreign liabilities were close to $80 \%$ GDP for South, with obvious consequences for its future net factor income payments. Periphery countries were forced to pay an increasing share of GDP to service its debt to foreign creditors, almost $6 \%$ of GDP in 2007.

\section{Next Financial Crisis Ahead}

Taylor (2011) define the period from the early 2000s as a period where macroeconomic policy became more interventionist, less rules-based, and less predictable. According to this thesis, the deviations from good policy started in 2003 with the Federal Reserve's decision to keep interest rates lower than dictated by the monetary guideline known as the Taylor rule and have continued through various bailouts and monetary easing and fiscal stimuli in the US and Europe.

Many studies have documented that excess returns (investment returns from a security or portfolio that exceed the riskless rate on a security generally perceived to be risk free) on financial market move in cycles. Researches on the interactions between different types of cycles have produced a number of important policy lessons. Economic theory moved toward the study of economic fluctuations rather than cycles, and the term "business cycle" lost its original meaning. Starting with Fisher (1933), a number of researches emphasize the importance of financial cycles for the real economy. Communale and Hessel (2014) find that financial cycle explains domestic demand movements better than

Figure 2. Net Public (left) and Private (right) Savings (1992-2007)

\section{Percent of GDP}

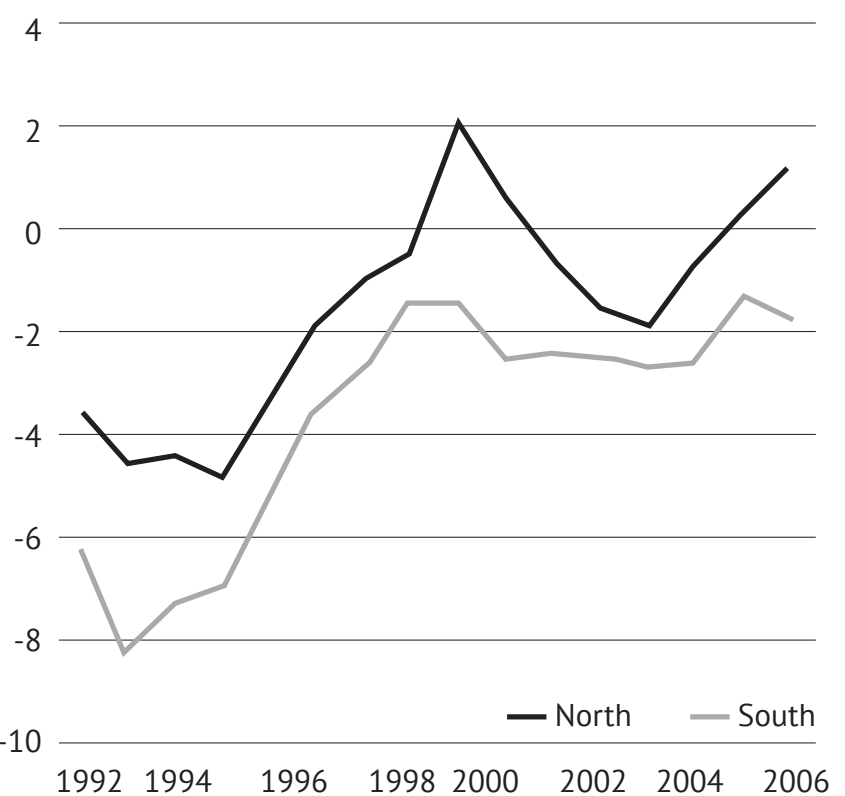

Percent of GDP

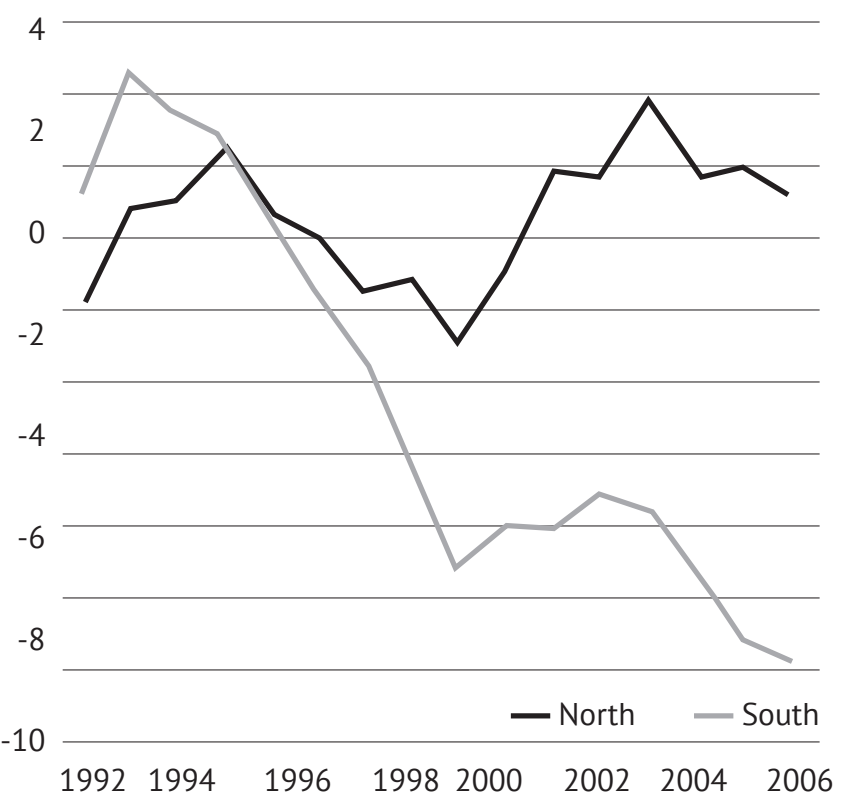

Source: Holinski et al. (2012) 
business cycle and that crisis countries experienced surprisingly similar divergences of financial factors, thus suggesting their importance. This finding is implicitly found also in Borio (2012). Studies (Forest et al., 2014) trying to asses the current position in the cycles through the prism of historical combinations of the business financial and monetary cycles suggest that, while business and monetary cycles move in tandem most of the time, financial cycles appear to follow their own path. They also find that business cycle expansion is clearly beneficial for risky bonds, while the re-leveraging and house price increases that take place during the financial cycle expansion tend to lower the returns on corporate bonds. Finally, the utmost priority, after synthesizing the changes in business, financial, and monetary cycles, is still to correctly measure the probabilities of the cycles moving into the contraction or expansion phase.

According to Dalio (2017), there are two important cycles to pay attention to: short-term debt cycle and the debt super cycle (or long-term debt cycle). A debt super cycle is defined by the period since the Second World War in which debt levels have inched persistently higher. This trend has been driven by the use of monetary policy in the wake of shocks. The policy's response ended in unsustainable levels of first private and now public debt. Lo and Rogoff (2015) argue that the financial crisis/debt supercycle view provides much more accurate and useful framework for understanding what has transpired and what is likely to come next. The symptoms of excessive debt are exhibiting themselves in the form of continued low economic growth and excessive volatility. As of 2017, we are eight years into the expansion phase of the business/short-term debt cycle, which lasts about eight to 10 years - and near the end of the expansion phase of long-term cycle, which typically lasts 50-75 years.

In this moment (June 2017), we believe that the developed markets are in an extremely dangerous situation. While record high stock and bond prices have become more detached from economic reality than ever before, some central bankers have encouraged debt level to surge to a record as well. Massive debt and leverage have simply shifted from primarily a private sector problem to an even larger public sector problem. Observers (Pento, 2017) find that, with major indices and stock indicators continuing to set record highs, there is further evidence that Wall Street is becoming more complacent with the growing dichotomy between equity and bonds prices (both moving higher) and the underlying strength of the US economy. The same picture is seen in European markets. Comparing total market cap to GDP, it becomes strikingly clear that economic growth has not at all kept pace with booming stock and bond prices in the past five years. The huge debt has been busted from new debt issuance, and debt compulsion which is the result of QE and zero interest rate policy.
There are different views about the danger of recent bubble: the Warren Buffet view is that the market isn't expensive, the American economy is doing well and long term investor should always be engaged; the same position hold Morgan Stanley strategists: they do not believe that the current forward $\mathrm{P} / \mathrm{E}$ is excessive in light of exceptionally low interest rate environment. They find conceptually invalid to compare P/E ratio today to, say, ratio in the early 1980's when interest rates were in double digits. However, there is a growing number of financial experts that expect an upcoming financial crisis. Especially US markets are experiencing level of risk that is the highest since the 2008 financial crisis. The potential causes of crash scenario on Wall Street are building. Downsize risks stem from several potential factors. Let us review some indicators that represent serious warning signals:

S\&P 500 is overvalued almost on any metrics. More than a dozen measures of the markets' valuation are trading above their historical average. The Case Shiller CAPE ratio, which has a 10 -year average of 16 , is currently at 30; accordingly, the S\&P 500 is overvalued by $75 \%$. The ratio has only been higher twice. Analysts of Bank of America Merill Lynch (Oyedale, 2016) point to the fact that median P/E is nearing tech bubble levels. The stocks most responsible for pulling up the P/E ratio where mid-caps, with the median stock in this category trading more than 92nd percentile of its history and 18 of 20 popular valuations of the stock market rate the S\&P 500 as overvalued, one as high as 105\% (WTI crude oil terms). Another key valuations metric is the Warren Buffet indicator, which compares the total price of all publicly traded companies to GDP. A reading over 100\% indicate overvaluation. The market cap to GDP is currently at $127 \%$. This indicator has only been higher twice since 1950 .

Following the fact that riskier indices form a top before the overall market form a top (a lesson learned from the stock market crash 2008-2009; we can see that from the Russel 2000 small cap index, which is an index that tracks performance of small capitalization companies) deemed riskier than mega-cap companies, has been outright flat with downward momentum indicators, while the major key stocks indices are moving higher. This could be an early indicator of a stock market drop.

The momentum is also important. A growing number of S\&P stocks are below their 200-day moving averages, as the index charges forward into unchartered territories. This suggest that the market is held up by only a handful of winning stocks. The market may be due to harsh correction.

Hussman (2017) calls the current environment "the most broadly overvalued moment in market history." His main point is that, back in 2000 and 2007, there were a relatively 
Figure 3. Case Schiller CAPE Ratio

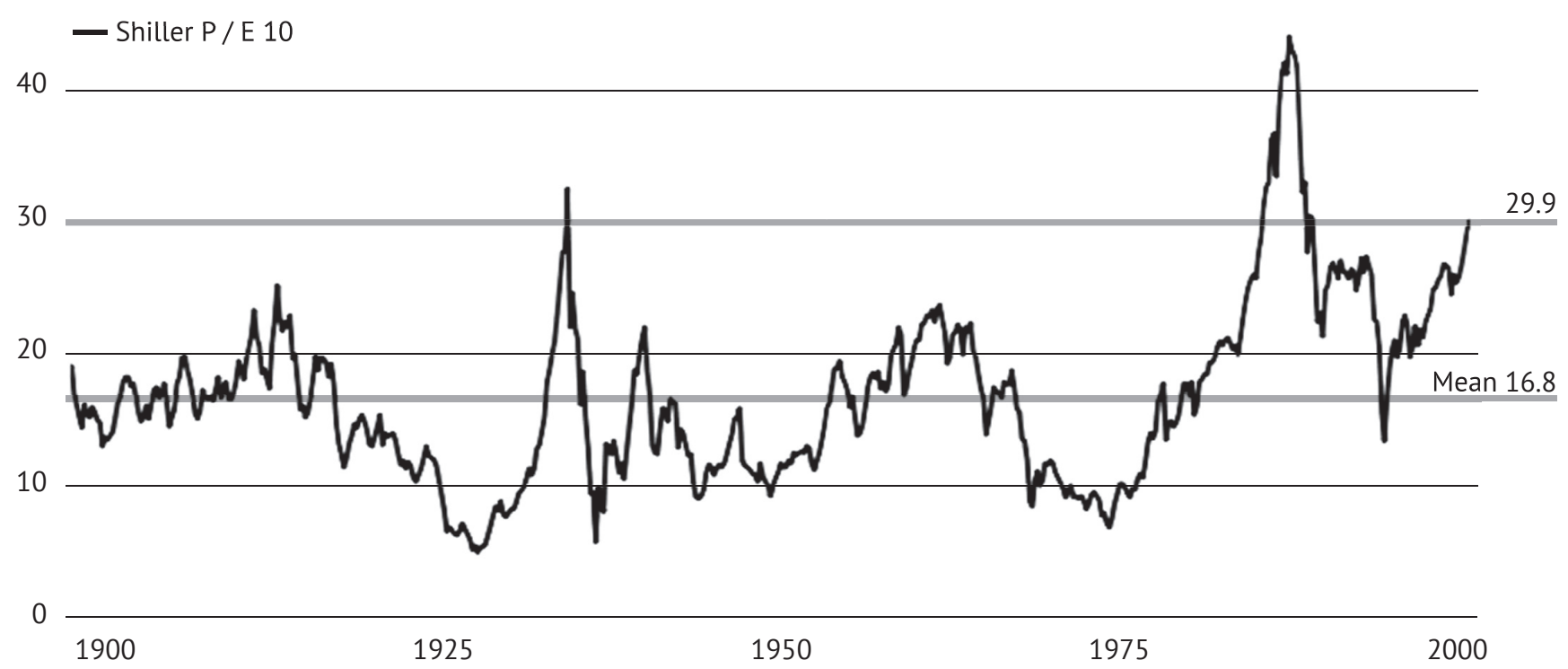

Source: https://www.gurufocus.com/shiller-PE.php

small group of super expensive stocks that drove the average valuation of the stock market much higher than normal. Today is the median, not the mean; the S\&P 500 valuation sits well above the peaks seen in 2000 and 2007, indicating that there are far more companies these days that share trade at much higher-than-normal valuation.

Many investors used the record bull market of S\&P 500 to intensify the use of margin debt. In February 2017 the margin debt on NYSE hit the record the record of \$530 billion. Such speculation, which coincides with the high on the stock market, represents a clear hint before a huge correction. This scenario is a déjà vu: in March 2000 margin debt hit the record together with the record high of S\&P 500; the same case happened in 2007, when credits achieve the record in July, just three months before the S\&P 500. This picture is confirmed also in relation to GDP, where records were achieved in 2000 and 2007 (Figure 4).

Stocks in the US are overpriced also by other metrics - and there's a bubble. The economic fundamentals are simply not strong enough to warrant the current market values. If we define a bubble as any prolonged phenomenon where a stock's value grows faster than a company's profit, then it is clear that, for profits to continue, economic growth at a global level should be healthy. This is not the case because world GDP levels are not high enough. The Willshire500-to-GDP also indicates overvaluation. This index is a marked-cap weighted index of all stocks actively traded US headquarters that trade on major exchanges. The ratio is at an all-time high of around 149. Volatility indicators are also warning: VIX hitting lows hints at a sell-off ahead. Over the past 17 years we have seen that, whenever the VIX turns lower, we have market tops in the works, and, a few months later, a stock market crash follows. This scenario happened in 2007. Currently, the VIX stands at its lowest level since 2007 (Zulfigar, 2017).

US household indicators also deserve attention. Personal disposable income in the US has been on the decline since late 2014. If we compare US household financial assets invested in the stock market vis-à-vis to those in money market funds, the direct result of seven years of zero percent interest rate policy can be seen. Households have now more than 15 times as much money invested in stocks than they do in money market funds, which is a picture well beyond anything we have ever seen. The warning signal also is coming from the side of average equities portfolio allocation of US households. It is a contrary indicator with high allocation correlated (R-squared of 0.913 ) with poor subsequent returns - and vice versa. Currently, US households collectively have $39.2 \%$ of their financial assets invested in equities. This has been only one other time since 1950, when this allocation was any higher and that was in late 1990s. The standing ahead of 2008 financial crisis was 37.5\%.

Asset managers and advisers do not like a sudden stop of quantitative easing policy. They have a fear against so-called tourists on the capital market, i.e., investors who usually invest only in safe papers; due to low yield, however, they began in the last years to invest heavier in riskier assets, so they could react with panic if the end of purchases will bring price drops for risk assets. On the high yields market we find around 30\% buyers, who have no experience with such 
Figure 4. NYSE Margin Debt and the S\&P 500 Real Growth Since 1995

\section{NYSE Margin Debt and the S\&P $500 \quad$ dshort.com Real Growth Since 1995 \\ $\longrightarrow$ Recessions $\rightarrow$ Real NYSE Margin Debt Growth $\rightarrow$ Real S\&P 500 Growth}

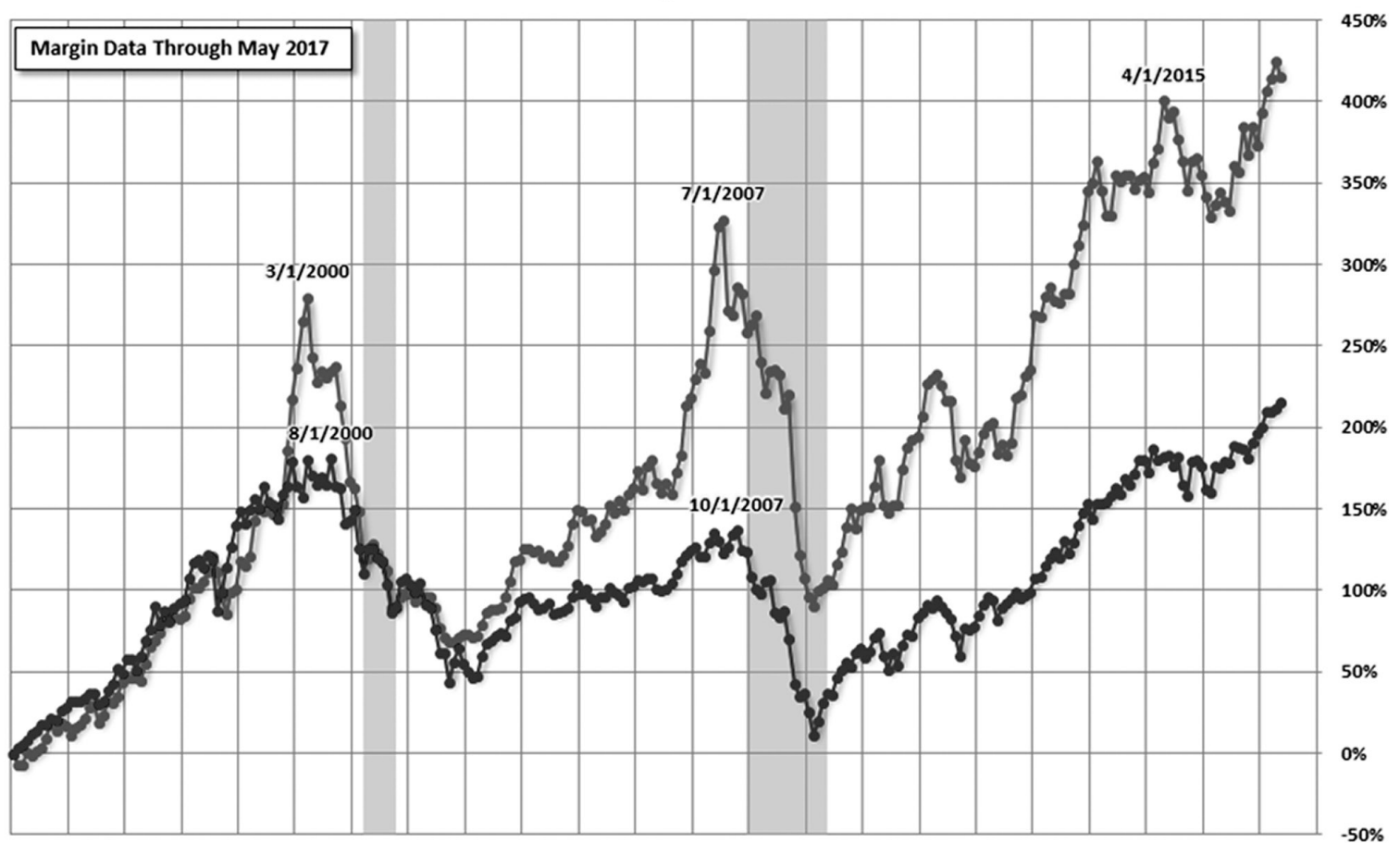

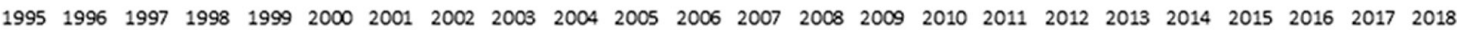

Source: Mislinski (2017)

assets. However, we see problems in the financial industry as well. Rickards (2016) finds that leveraged positions of banks are still managed on the prevailing theory of VaR, i.e., value at risk. This theory assumes that risk in long and short positions are nettled, the degree distribution of price movements is normal, and extreme events are exceedingly rare and derivatives can be properly priced using a "risk-free" rate. The problem is all four of the assumptions are false.

Analysts (Durden, 2017) differentiate among narrative and credit-driven bubbles. The first one is based on a story, or new paradigm, that justifies abandoning traditional valuation metrics (Nifty, Fifty bubble of early 1970s, dot.com bubble of 1990s). We are globally now in a credit-driven bubble, which doesn't need a narrative or a good story - just easy money. A credit bubble bursts when the credit dries up. There are already signs that hint of an impending bubble burst: interest rate hikes, preparations for QE reversals, tighter credit conditions. Actual FED projections forecast a $3 \%$ yield on 10-year treasuries, accordingly dividend yield on S\&P 500 (obtained by a 12-month dividend per share/ price) is around $2 \%$. This is strong argument in favour of possible strong market correction.

Many investors are worried about the fact that investors are ignoring the real economy and focusing too much on the financial economy. Some experts (Dalio, 2017) confirm this position and suggest that the problem is wider; namely, they don't see the problem as coming from the market themselves, as much as the author does from the overall economic and political situation (debt, Trump, N. Korea, etc.)

The fact is that a small trigger can lead to major financial crisis: subprime mortgage market with $4 \%$ of the overall mortgage market in the US crisis of 2007 or Greek debt problems in the euro crisis of 2010. Modern financial technology affect triggers of contagion: in the 1930s case, the panic begin with the run on small-town banks and spread until it hit the stock exchange. Today the financial panic starts in a computer algorithm, which triggers preprogrammed sell orders that cascade into other computers until the system spins out of control. Hence, likely triggers could include a cyber-financial attack, a major bank failure, and many other events. Because the system itself is of unprecedented scale and interconnectedness, the new crisis could be of unprecedented scale (Rickards, 2016). Modern markets are not only more complex, but the problem is worse because derivatives allowed asset liability mismatch (short-term borrowing and long-term landing) to be more highly leveraged and spread among more counterparties. 


\section{Conclusion}

Considering the "this time is different syndrome," we agree with those economists (Kindelberger, Reinhardt, Rogoff, etc.) who advocate the position that the behaviour of investors and government remains constant through history. There are enough signs that the public is not willing to learn. Old lessons are not embodied in behaviour. Speculative investing can lead to stock market crash and financial crisis. Fueling the bubble is the fear of missing out (FOMO) trade. Ever since the South Sea Trading Company bubble of 1720 , the most common cause of irrational asset prices rises has been the FOMO.

Many respected market analysts see an abnormal market environment. By holding short-term interest rates near zero, the central banks have encouraged malinvestment and speculations. The cyclical bull market in stocks, bonds, and housing that began in early 2009 has developed into one of the largest bubbles of the past 100 years. The current stock and bond environment on developed markets is looking a whole lot like the dot.com stock market bubble in 19981999 and the subprime bubble in 2007.

Different indicators are showing that stocks and bonds are priced far above their fundamental value. Historically low interest rates and huge share buybacks have helped fuel explosive security markets higher and pushed security prices to the historical highs. The Shiller P/E ratio has risen to levels only matched before the 1929, 2000, and 2007 bubble burst.

Unlike the financial crisis of 2000, which was defined by the stock market crash, and the 2008 subprime crisis, which was about stocks and housing, in 2017 the story is defined dangerously wider, namely by stocks, bonds, and debt. The element that poses a warning is not the unusual bull market - the second longest since World War II, and not the fact that S\&P soared more than 260\% since bottoming at 666 on March 6, 2009, but the point that bull market has been fueled more by the central banks' easy monetary policy than years of strong earnings and revenue growth, and the point that the US debt levels are soaring. Having in mind the well-known contagious impact of US events and trends on global economy in previous crashes and crises, the world has to carefully observe ever longer debt and bubble levels. The conditions for collapse are all in place. The financial environment is ready for the next financial crisis. Possible black swan events are waiting.

\section{Acknowledgments}

The author acknowledges the financial support from the Slovenian Research Agency (research core funding No. P5-0027).

\section{References}

Alessandrini P., Hughes H. A., Presbitero A. F., \& M. Fratianni. (2012). The Eurozone crisis: Fiscal fragility, external imbalances, or both? VOX CEPR's Policy Portal.

Baily, M., R. Litan, \& M. Johnson. (2008). The origins of the financial crisis. Business and Public Policy at Brookings. Fixing Finance Series-Paper 3.

Borio C. (2012). The financial cycle and macroeconomics: what have we learnt? BIS Working Papers, No. 395.

Chinn, M. D., \& J. A. Frieden. (2012). The eurozone in crisis: Origins and prospects. La Follette School Working Paper No. $2012-001$.

Comunale, M., \& J. Hessel. (2014). Current account imbalances in the euro area: Competitiveness of financial cycle. DNB Working Paper No. 433. https://doi.org/10.2139/ssrn.2509303

Dadush, U., \& Z. Wyne. (2012). Is the euro rescue succeeding? An update. VoxEu.org. Available http:// http://voxeu.org/ [20.04.2014].

De Grauwe, P., \& Y.Ji. (2012). Self-fulfilling crisis in the eurozone: An empirical test. CEPS Working Document, 336.

De Long, B., \& L. Summers. (2012). Fiscal policy in depressed economies. Brooking Papers in Economic Activity. March 2014.

Drehmann, M., C. Borio, \& K. Tsatsaronis (2012). Characterising the financial cycle: don't lose sight of the medium term! BIS Working Papers, No. 380.

Durden, T. (2017). The bubble that could break the world. Retrieved from http://www.zerohedge.com/news/2017-05-25/bubble-couldbreak-world.

Fischer, I. (1933). The debt-deflation theory of great depression. Econometrica. https://doi.org/10.2307/1907327

Forest, N., T. Orpiszewski, A. Péters, \& G. Kojo. (2014). Riding the cycles: Understanding business, financial and monetary cycles in order to allocate fixed income. White Paper. Candriam Investors Group. New York.

Greenlaw, D., J. Hatzins, A. Kashyap, \& H. Song Shin. (2008). Leverage losses: Lessons from the mortgage meltdown. University of Chicago and Rosenberg Institute.

Higgins, M., \& T. Klitgaard. (2011). Saving imbalances and the euro area sovereign debt crisis. Federal Reserve Bank of New York, 17(5), pp. 1-11. https://doi.org/10.2139/ssrn.1925018

Holinski, N., Kool, C., \& J. J. Muysken. (2012). Persistent macroeconomic imbalances in the euro area: Causes and consequences. Federal Reserve Bank of St. Louis Review, 94(1), pp.1-20.

Hussman, J. (2017). The most broadly overvalued moment in market history. Hussman Funds-Weekly Market Comment. 
https://www.gurufocus.com. (2017). Shiller P/E:A Better measurement of market valuation. Retrieved from https://www.gurufocus.com/ shiller-PE.php.

Jordà, O., M. Schularick, \& A. Taylor. (2011). Financial crises, credit booms, and external imbalances: 140 years of lessons. IMF Economic Review, 59(2), p. 340-378. https://doi.org/10.1057/imfer.2011.8

McKinney, R. (2017). Morgan Stanley says ride the raging bull. Retrieved from http://thestockhustle.com/index.php/2017/04/18/morgan-stanley-says-ride-the-raging-bull/.

Merler, S. and J. Pisani-Ferry. (2012). Sudden stops in the Eurozone. VoxEu.org. Retrieved from http://voxeu.org/ [20.04.2014].

Mishkin, F. (2010). Over the cliff: From the subprime to the global financial crisis. NBER Working Paper, 16609.

Mislinski, J. (2017). A Look at NYSE Margin Debt and the Market. Retrieved from https://www.advisorperspectives.com/dshort/updates/2017/08/01/a-look-at-nyse-margin-debt-and-the-market.

Moshinsky, B. (2017). Ray Dalio: The 75-year debt super cycle is coming to an end. Business Insider UK, Jan 27.

Oyedale, A. (2016). Bank of America: Stocks are almost as expensive as they were during the tech bubble. Business Insider, Oct. 12.

Pento, M. (2017). Here's what the market could do for the 3rd time in 17 years. Retrieved from http://www.talkmarkets.com/content/ bonds/heres-what-the-market-could-do-for-the-3rd-time-in-17-years?post=126432.

Rickard, J. (2017). The instability of the system is something we should be all concerned about. Retrieved from http://jimrickards. blogspot.si/.

Rickard, J. (2016). The road to ruin: The global elite's secret plan for the next financial Crisis. Penguin.

Rogoff, K. (2015). Secular stagnation, debt overhang and other rationales for sluggish growth, six year on. BIS. Working Paper, No. 482.

Sanchez, J. L. D., \& A. Varoudakis. (2014). Tracking the causes of Eurozone external imbalances: New evidence. VOX CEPR's Policy Portal.

Schularick, M., \& A.M. Taylor. (2012). Credit booms gone bust: monetary policy, leverage cycles and financial crises, 1870-2008, NBER Working Paper No. 15512.

Shirai, S. (2009). The impact of the US subprime mortgage crisis on the world and East Asia. Munich Personal RePEc Archive.

Sinn, H. W., \& T. Wollmershäuser. (2011). Target loans, current account balances and capital flows: The ECB's rescue. CESifo Working Paper 3500. CESifo, Munich CrossRef. https://doi.org/10.3386/w17626

Strasek, S., \& B. Bricelj. (2015). Subprime and global origins of Euro sovereign crisis. The Business Review, 23(1), 61-67. [COBISS.SI-ID 12003868]

Taylor, J. (2011). Macroeconomic lessons from the great deviation. NBER Macroeconomic Annual, 25(1). https://doi.org/10.1086/657553

Zulfigar, M. (2017). This charts make a case for a stock market crash in 2017. Lombardi Letter, March 9.

\section{Author}

Sebastjan Strašek is a full professor of economic policy at the Faculty of Economics and Business, University of Maribor. He received his B.A. in economics from the University of Zagreb, Croatia, and his Ph.D. in economics from the University of Maribor. He has written widely on various aspects of financial crises, including business cycles, behaviour of capital markets, and different aspects of stock trends. He is currently the chair of the Department of Economic Policy at the Faculty of Economics and Business in Maribor.

\section{Od krize drugorazrednih posojil in evrske krize $s$ polno hitrostjo $v$ novo finančno krizo}

\section{Izvleček}

Članek podaja analizo prehoda od krize drugorazrednih posojil in evrske krize do elementov nove sistemske krize. Namen naše raziskave je raziskati skupno problematiko, ki spremlja te krize, in proučiti elemente, ki sugerirajo trend premika $v$ novo krizo. Z vzdrževanjem kratkoročnih obrestnih mer blizu nič so centralne banke hrabrile napačne investicijske odločitve in špekulacije. Napihovanje balona je povezano s fenomenom strahu pred izgubo priložnosti. Menimo, da aktualni dogodki in premiki na trgu vrednostnih papirjev sledijo tipičnemu vzorcu, ki kaže na resno grožnjo naslednje finančne krize. Identificirali smo številne znake, da lekcije starih kriz niso bile upoštevane.

Ključne besede: finančna kriza, balon, količnik P/E 